\title{
Effect of Cropping Pattern and Fertilizer Doses Applied in Raised-Bed on The Growth and Yield of Rice (Oryza sativa L.) in Sunken-Bed of The Surjan Rice Field
}

\author{
Damar Suryaningndari, Didik Indradewa, Budiastuti Kurniasih*, and \\ Endang Sulistyaningsih
}

Faculty of Agriculture, Gadjah Mada University, Bulaksumur, Yogyakarta 55281

Jln. Flora no. 1, Bulaksumur, Sleman, Yogyakarta 5528, Indonesia

*Corresponding email: tuti_b@ugm.ac.id

\begin{abstract}
Surjan system (alternating bed system) is an agricultural system that combines dry and wet bedding system. It integrates food crop culture in the sunken-bed and annual crops in the raised-bed of the rainfed rice field. In Bantul, farmers commonly apply Surjan system in rice field by growing shallot (Allium cepa L. aggregatum group) and chili (Capsicum annuиm L.) in the raised-bed, whereas no crop is grown in the sunken-bed. The purpose of this study was to determine the effect of cropping pattern and fertilizer dose applied in raised-bed on the growth and yield of rice in sunken-bed of the Surjan rice field. This study were arranged in a split plot design with three replication. The main plot consists of two cropping pattern, namely shallot monoculture and intercropping shallot with chili. The fertilizer dose applied in raised-bed, namely 100\% farmer's habit; $50 \%$ farmer's habit; and 25\% farmer's habit, occupying the sub plot. Dose of fertilizer applied in riased-bed according to the farmer's habit in research location is $622 \mathrm{~kg}$ NPK.

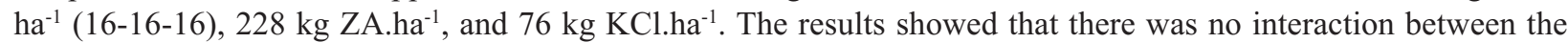
cropping pattern and the fertilizer dose applied in the raised-bed on the growth and yield of rice in the sunken-bed. Compared with shallot monoculture, intercropping shallot with chili in raised-bed decreased the growth of rice in the sunken-bed. Compared with the $100 \%$ fertilizer dose of farmer's habits, the fertilizer dose of $50 \%$ of the farmer's habits in the raised-bed increased the growth of rice in the sunken-bed. However, cropping pattern and fertilizer dose in the raised-bed did not significantly affect the rice yield grown in the sunken-bed of the Surjan rice field.
\end{abstract}

Keywords: Intercropping shallot with chili, land intensification, shallot monoculture, Surjan rice field

\section{INTRODUCTION}

Agricultural intensification is one of ways to increase rice production (Sianipar et al., 2009). Agricultural intensification is increasing the amount of food produced per unit of land (Gover et al., 2017). The selection of cropping patterns became part of agricultural intensification in order to increase crop production.

The scope of cropping patterns is the management of crop types and arrangements according to the dimensions of space and time. Cropping pattern consists of single planting pattern (monoculture) and multiple cropping pattern (multiple cropping). In multiple cropping, it is generally argued that the practice favors an efficient utilization of resources like air, water, light, space, and nutrients by companion crops in both temporal and spatial dimensions due to their differential growth habits and seasonality. Multiple cropping could be one of the viable alternatives to cope uncertainties and changes, where food and nutritional uncertainty looming large (Paudel, 2016). Intercropping is a ways to increase diversity in an agricultural ecosystem. Ecological balance, more utilization of resources, increases the quantity and quality of products and reduction damage by pests, diseases and weeds will increases with use of intercropping systems (Mousavi and Iskandari, 2011).

Intercropping pattern in agricultural intensification provides several benefits for farmers. The advantages of intercropping pattern is to minimize the risk of crop failure because the plant type cultivated is more than one. Based on Jabbar et al. (2010), the grain yield of rice 
grown with intercropping pattern was significantly higher than that of grown with monoculture pattern. The highest yield of rice grain was obtained on the intercropping rice with maize, followed by rice with cowpea and rice with Sesbania and the lowest grain yield was obtained from monoculture pattern. In addition, the added nutrients (fertilizers) can be absorbed more leverage because there are more than one type of plant in one similar field so that the possibility of nutrient loss becomes lesser (Masbidin, 2016).

Application of intercropping pattern can be done with Surjan system. Surjan system (alternating bed system) is an agricultural system that integrates rice field system and mooring system. The word 'Surjan' is derived from the Javanese word meaning striate or lines (Nursyamsi and Haryono, 2014). Striped pattern is a stretch of sunken and raised-bed, where each bed planted with different plant types. The advantage of using Surjan is that farmers can diversify commodities so that it will reduce the risk of failure (Thohiron and Prasetyo, 2012).

Surjan system is widely applied in swamp areas to overcome the problem of land and water management. Arrangement of land with Surjan system is intended to diversify crops. The cropping patterns that can be applied in the sections of raised-bed are cereals, pulses or horticultural crops, while in the sunken-bed is rice (Nazemi et al., 2008). According to Jumakir and Endrizal (2017), the management of swamp land with Surjan system can increase rice productivity by $41.97 \%$ and provide farmers income of $\mathrm{Rp} 6,914,000$ ha $^{-1}$.

Surjan system can be applied in rice field. It is characterized by striped lines when looked from above. According to Aminatun (2009), rice fields with Surjan system can be used as an alternative to manage rice fields that involves biotic, abiotic and human components. The application of Surjan rice field is the adaptation of farming communities towards low and easily flooded topography. The sunken-bed is commonly planted with rice, while the raised-bed is commonly planted with cereals and pulses (palawija). The raised-sunken-bed is made as a way to manage the drainage. In addition, the application of ricepalawija cropping patterns make the ecosystem of Surjan rice field more stable than rice fields that are only planted with rice.

The management of rice field with Surjan system has been applied by farmers in Bantul Regency especially Samas Region. Currently, the crops that farmers usually selected are still limited to horticultural crops such as shallot or intercropping red shallot with chili in the raised-beds. The sunken-bed has not been used for cultivation of plants and is only used as a water storage to water the plants in the raisedbeds. The sunken-bed that have not been utilized by farmers actually has the opportunities for rice cultivation.

Hopefully, rice grown in sunken-bed can utilize fertilizer runoff from the raised-beds in order to grow and yield which mean that the rice crop is not fertilized directly. This is done to minimize inputs. The utilization of the sunken-bed for rice cultivation is expected to be an alternative to increase rice production and farmer profits.

Rice cultivation in the sunken-bed is done under the raised-beds that are planted with the main crop. According to the farmer's habit in Samas, the raisedbed is planted with red shallot or intercropping shallot with chili. The fertilizer dose for shallot in the raisedbeds according to the current farmer's habits is 622 kg NPK ha-1 (16-16-16); $228 \mathrm{~kg} \mathrm{ZA} \mathrm{ha}^{-1}$ and $76 \mathrm{~kg}$ $\mathrm{KCl} \mathrm{ha}{ }^{-1}$. According to the farmer's habit in Samas, the chili is not fertilized and acts as an additional plant that is planted on the sidelines of shallot. According to Badan Penelitian dan Pengembangan Pertanian, the recommended fertilize dose for shallots in paddy fields is $180 \mathrm{~kg} \mathrm{~N} \mathrm{ha}^{-1} ; 90 \mathrm{~kg} \mathrm{P} \mathrm{ha}^{-1}$; and $50-100 \mathrm{~kg}$ $\mathrm{K}^{-1}{ }^{-1}$ (Setiawati et al., 2007). The current fertilizer given by farmers is higher than the recommendation, so for the next opportunity the fertilizer dose may be lowered. In addition, the price of fertilizer is quite expensive and it brings the negative impact for the environment.

The utilization of the sunken-bed for rice cultivation by utilizing fertilizer run off from the raised-bed need to be studied further since there is no information about the growth and yield of rice cultivated in the sunken-bed. The cropping pattern and the fertilizer dose in the raised-bed is suspected to have an effect on the growth and yield of rice in Surjan rice field. The purpose of this study was to determine the effect of cropping pattern and the fertilizer dose applied in raised-bed on the growth and yield of rice in sunkenbed of the Surjan rice field.

\section{MATERIALS AND METHODS}

This research was conducted at Samas beach area, Srigading Village, Sanden Subdistrict,Bantul Regency. Yogyakarta on August-November 2016. The rice cultivar used was Inpari 29.

The experimental design used in this research was split plot design. The main plot was the pattern 
of planting in the raised-bed (T), i.e. $\mathrm{T} 1=$ shallot monoculture and $\mathrm{T} 2$ = intercropping of shallot with chili. The experimental plot was the fertilizer dose in the raised-bed $(\mathrm{P})$, i.e. $\mathrm{P} 1=100 \%$ farmer's habits [622 kg NPK ha-1 (16-16-16) + $228 \mathrm{~kg} \mathrm{ZA} \mathrm{ha}^{-1}+76$ $\left.\mathrm{kg} \mathrm{KCl} \mathrm{ha}^{-1}\right] ; \mathrm{P} 2=50 \%$ farmer's habits [311 kg NPK $\mathrm{ha}^{-1}(16-16-16)+114 \mathrm{~kg} \mathrm{ZA} \mathrm{ha}^{-1}+38 \mathrm{~kg} \mathrm{KCl} \mathrm{ha}^{-1}$; and $\mathrm{P} 3=25 \%$ of farmers' habit $\left[156 \mathrm{~kg}\right.$ NPK ha ${ }^{-1}$ (16-16-16) + $\left.57 \mathrm{~kg} \mathrm{ZA} \mathrm{ha}^{-1}+19 \mathrm{kgKCl} \mathrm{ha}{ }^{-1}\right]$.

Rice grown in the sunken-bedwas done alternately, i.e., one sunken-bed planted with rice, the next one was not planted with rice, so that it did not disrupt the function of the sunken-bed as a water storage that would be used to water the main crops in the raisedbed. Rice aged 23 days after seedling (DAS) was transplanted to the sunken-bed and planted with a distance of $20 \mathrm{~cm} \times 20 \mathrm{~cm}$. Rice plants in the sunken-bed were not fertilized due to the expectation that it could utilize the fertilizer runoff from the raised-bed. The number and plant spacing of shallot both in raised-bed with monoculture and intercropping cropping pattern were similar.

The variables observed during the experiment were leaf area index (LAI), net assimilation rate (NAR), crop growth rate (CGR), plant dry weight, plant height, number of panicles, panicle length, number of grains per panicle, percent of filled grain, grain weight per hill, 100 grain weight, rice productivity and harvest index (HI). The data were then analyzed by using SPSS Statistics 21 for Windows with Two Way Analysis of Variance (ANOVA). Mean comparison was done according to Duncan Multiple Range Test (DMRT) with 5\% significance level.

\section{RESULTS AND DISCUSSION}

\section{Growth component of rice grown in the sunken- bed}

Plant growth could be defined as the increasing of plant volume and/or mass with or without formation of new structures such as organs, tissues, cells or cell organelles. Growth is usually associated with development (cell and tissue specialization) and reproduction (production of new individuals) (Brukhin and Morozova, 2011). Crops tend to distribute assimilate most of the early growth phase in the form of the addition of leaf area in order to make use of sunlight efficiently (Gardner et al., 2008). The formation and the addition of leaf size affect the leaf area index (Pratiwi, 2005).

The results showed that there was no interaction between the cropping pattern and the fertilizer dose applied in the raised-bed in affecting the LAI of rice grown in the sunken-bed. LAI of rice grown in the sunken-bed was also not affected by the cropping pattern and the fertilizer dose in the raised-bed (Table 1).

LAI determined the photosynthetic activity through the absorption of sunlight by the leaf surface (Lindroth et al., 2008). The lower photosynthetic activity caused NAR to decrease and vice versa. An increase of LAI will be followed by an increase of photosynthetic activity up to the maximum LAI value so that it can decrease the photosynthetic rate (Sitompul and Guritno, 1995). The results showed that NAR of rice plants under the raised-beds with the intercropping shallot with chili was lower than that of rice plants under the raised-beds with shallot

Table 1. Leaf area index (LAI), net assimilation rate (NAR), crop growth rate (CGR), plant dry weight (PDW), and plant height $(\mathrm{PH})$ of rice grown in sunken-bed as affected by cropping pattern and fertilizer dose applied in raised-bed

\begin{tabular}{|c|c|c|c|c|c|c|c|c|}
\hline \multirow{2}{*}{ Treatment } & \multicolumn{2}{|c|}{ LAI } & NAR & CGR & \multicolumn{3}{|c|}{ PDW (g) } & \multirow{2}{*}{$\frac{\mathrm{PH}(\mathrm{cm})}{8 \mathrm{WAP}}$} \\
\hline & 23 DAP & 55 DAP & $\left(\mathrm{g} \mathrm{dm}^{-2}\right.$ week $\left.^{-1}\right)$ & 1) $\left(\mathrm{gdm}^{-2}\right.$ week $\left.^{-1}\right)$ & 23 DAP & 55 DAP & Harvest & \\
\hline \multicolumn{9}{|l|}{ Cropping pattern (a) } \\
\hline Monoculture & $0.26 \mathrm{a}$ & $1.72 \mathrm{a}$ & $1.16 \mathrm{a}$ & $0.91 \mathrm{a}$ & $1.43 \mathrm{a}$ & $19.56 \mathrm{a}$ & $33.33 \mathrm{a}$ & $68.98 \mathrm{a}$ \\
\hline Intercropping & $0.21 \mathrm{a}$ & $1.04 \mathrm{a}$ & $0.86 \mathrm{~b}$ & $0.46 \mathrm{~b}$ & $1.26 \mathrm{a}$ & $10.54 \mathrm{~b}$ & $31.73 \mathrm{a}$ & $65.57 \mathrm{a}$ \\
\hline \multicolumn{9}{|c|}{ Fertilizer dose in raised-bed (b) } \\
\hline $100 \%$ farmer's habit & $0.25 \mathrm{p}$ & $1.14 \mathrm{p}$ & $0.90 \mathrm{q}$ & $0.53 \mathrm{q}$ & $1.27 \mathrm{p}$ & $11.81 \mathrm{q}$ & $33.86 \mathrm{p}$ & $68.11 \mathrm{p}$ \\
\hline $50 \%$ farmer's habit & $0.26 \mathrm{p}$ & $1.72 \mathrm{p}$ & $1.21 \mathrm{p}$ & $0.94 \mathrm{p}$ & $1.57 \mathrm{p}$ & $20.28 \mathrm{p}$ & $32.79 \mathrm{p}$ & $66.36 \mathrm{p}$ \\
\hline $25 \%$ farmer's habit & $0.21 \mathrm{p}$ & $1.28 \mathrm{p}$ & $0.93 \mathrm{q}$ & $0.59 \mathrm{q}$ & $0.21 \mathrm{p}$ & $13.06 \mathrm{q}$ & $30.93 \mathrm{p}$ & $67.35 \mathrm{p}$ \\
\hline$\overline{\text { Mean }}$ & 0.24 & 1.38 & 1.01 & 0.69 & 1.15 & 15.05 & 25.41 & 67.27 \\
\hline $\mathrm{CV}$ a (\%) & 9.30 & 12.89 & 4.50 & 12.29 & 12.01 & 12.05 & 10.88 & 5.47 \\
\hline $\mathrm{CV} b(\%)$ & 11.38 & 12.89 & 10.07 & 15.35 & 15.34 & 14.33 & 16.40 & 5.79 \\
\hline
\end{tabular}

Remarks: The mean in one column followed by the same letter wase not significantly different according to DMRT ( $\alpha$ 5\%) 
monoculture (Table 1). This because LAI of rice grown under the raised-bed with intercropping pattern shallot with chili tend to be lower than LAI of rice grown under the raised-bed with shallot monoculture. The higher number of tillers was found in the treatment of the intercropping pattern of shallot with chili caused the nutrient (fertilizer) competition became higher, so caused the decreased in LAI. According to Yamuna et al. (2017), intercropping pattern increased total $\mathrm{N}, \mathrm{P}$ and $\mathrm{K}$ uptake. It lead to the fertilizer runoff for rice grown in sunken-bed that was allegedly fewer.

The fertilizer dose in the raised-beds affected NAR of rice plants in the sunken-bed. Compared to the fertilizer dose according to the farmer's dose, the reduction of the fertilizer dosage in the raised-beds to $50 \%$ of the farmers' habit lead to an increase in net assimilation rate of rice crops in the sunken-bed (Table 1). Reduction of the fertilizer dose in the raised-beds to $50 \%$ farmers' habits was expected to be more efficient, so that crops in the sunken-bed produced higher LAI. According to Kurniadie (2001), high levels of fertilizer dose and inappropriate timing led to lower fertilizer efficiency. The increased use of fertilizer was not proportional to the increase of plant growth and production.

Cropping pattern did not interact with the fertilizer dose in the raised-bed in affecting CGR. The growth rate of rice plants in the sunken-bed was affected by the cropping pattern in the raised-beds. Compared to shallot monoculture, intercropping shallot with chili in raised-bed reduced the CGR of rice grown in the sunken-bed (Table 1). It was because intercropping shallot with chili in raised-bed reduced the NAR and LAI of rice grown in the sunken-bed. According to Shipley (2006), NAR determined CGR.

The fertilizer dose in the raised-beds affected the growth rate of rice grown in the sunken-bed. Compared to the fertilizer dose according to the farmer's habits, the reduction of fertilizer dose applied in the raised-beds to $50 \%$ of the farmers' habit led to an increase in CGR in the sunken-bed (Table 1). The increasing NAR of rice under the raised-beds with $50 \%$ fertilizer dose of farmers' habits was strongly supported by LAI which tended to be higher so that it increased CGR significantly.

The plant dry matter illustrated the absorption efficiency and utilization of solar radiation available throughout the growth stage (Gardner et al., 2008). The higher CGR will result in higher dry weight of the plant. Rice grown under the raised-beds with shallot monoculture had higher total dry weight than rice grown under the raised-beds with the intercropping shallot with chili (Table 1). It was because the CGR of rice plants under the raised-beds with shallot monoculture was high. The intercropping shallot with chili in the raised-beds decreased CGR of rice grown in sunken-bed, so that the resulting plant dry weight decreased significantly.

The fertilizer dose in the raised-bed affected the total dry weight of rice grown in the sunken-bed. Rice under the raised-beds with the fertilizer dose according to the farmer's habits had significantly lower dry weight than the rice plants under the raised-beds with the $50 \%$ fertilizer dose of farmer habits at 55 DAP (Table 1). Increasing CGR of rice under the raised-beds with $50 \%$ fertilizer dose of farmers' habits would be followed by increased plant dry weight.

The plant dry weight could affect the plant height. The higher the accumulation of dry weight made the plant to grow taller. The plant height of rice grown in the sunken-bed as shown in Table 1 was not affected by the interaction of cropping pattern with the fertilizer dose applied in the raised-beds. The cropping pattern and the fertilizer dose in the raised-bed also did not affect the plant height of rice grown in the sunken-bed.

\section{Yield component of rice grown in the sunken-bed}

The division of dry matter as a result of photosynthesis determines the crop yield (Gardner et al., 2008). After entering the generative phase, the distribution of dry matter for the growth of leaves, roots and stems is limited. Most of the dry matter that is formed and stored is transferred to the generative parts of the plant. The panicle is one of the parts that get greater portion of dry weight. Not all plant tillers are able to produce panicles. Only productive tillers are capable of producing panicles. The results showed that there was no interaction between the cropping pattern and the fertilizer dose in the raisedbed on the number of panicles per hill of rice grown in the sunken-bed. The independent effect of cultivation pattern and the fertilizer dose in raised-bed on the number of panicles per hill in the sunken-bed was not significantly different (Table 2).

The other yield component of rice grown in the sunken-bed such as number of grains per panicle, percentage of filled grain, and 100 grain weight were not affected by the interaction between cropping pattern and fertilizer dose in the raised-bed. The cropping pattern and the fertilizer dose in the raisedbed did not affect the yield component of rice grown 
Table 2. Number of panicle, panicle length, number of grains per panicle, percent of filled grain, grain weight per hill, 100 grain weight of rice grown in sunken-bed as affected by cropping pattern and fertilizer dose applied in raised-bed

\begin{tabular}{lcccc}
\hline Treatment & $\begin{array}{c}\text { Number of } \\
\text { panicles }\end{array}$ & $\begin{array}{c}\text { Number ofgrains } \\
\text { per panicle }\end{array}$ & $\begin{array}{c}\text { Percentageof } \\
\text { filled grain (\%) }\end{array}$ & $\begin{array}{c}100 \text { grain weight } \\
(\mathrm{g})\end{array}$ \\
\hline $\begin{array}{l}\text { Cropping pattern in raised-bed (a) } \\
\text { Monoculture }\end{array}$ & $5.00 \mathrm{a}$ & $115.00 \mathrm{a}$ & $63.93 \mathrm{a}$ & $2.50 \mathrm{a}$ \\
Intercropping & $5.11 \mathrm{a}$ & $95.11 \mathrm{a}$ & $59.54 \mathrm{a}$ & $2.34 \mathrm{a}$ \\
\hline Fertilizer dose in raised-bed (b) & & & & \\
$100 \%$ farmer's habit & $5.67 \mathrm{p}$ & $106.67 \mathrm{p}$ & $67.94 \mathrm{p}$ & $2.46 \mathrm{p}$ \\
$50 \%$ farmer's habit & $5.00 \mathrm{p}$ & $107.50 \mathrm{p}$ & $58.72 \mathrm{p}$ & $2.37 \mathrm{p}$ \\
$25 \%$ farmer's habit & $4.50 \mathrm{p}$ & $101.00 \mathrm{p}$ & $58.55 \mathrm{p}$ & $2.45 \mathrm{p}$ \\
\hline Mean & 5.06 & - & 61.74 & 2.42 \\
\hline $\mathrm{CV} \mathrm{a} \mathrm{( \% )}$ & 23.87 & 5.10 & 13.34 & 2.03 \\
$\mathrm{CV} \mathrm{b}(\%)$ & 28.63 & 6.14 & 14.01 & 2.035 .79 \\
\hline
\end{tabular}

Remarks: The mean in one column followed by the same letter wase not significantly different according to DMRT ( $\alpha$ 5\%)

Table 3. Harvest index of rice grown in sunken-bed as affected-by cropping pattern and fertilizer dose applied in raised-bed

Cropping pattern in raised-bed

(a)

\begin{tabular}{lcccc}
\hline Cropping pattern in raised-bed & \multicolumn{3}{c}{ Fertilizer dose in raised-bed (b) } & \multirow{2}{*}{ Mean } \\
\cline { 2 - 4 } (a) & 100\% farmer's habit 50\% farmer's habit & $25 \%$ farmer's habit & \\
\hline Monoculture & $0.23 \mathrm{ab}$ & $0.14 \mathrm{c}$ & $0.26 \mathrm{a}$ & 0.32 \\
Intercropping & $0.23 \mathrm{ab}$ & $0.25 \mathrm{ab}$ & $0.15 \mathrm{bc}$ & 0.32 \\
\hline Mean & 0.23 & 0.20 & 0.21 & $(+)$ \\
\hline $\mathrm{CV}$ a (\%) & & & 11.45 \\
CV b (\%) & & 28.63 \\
\hline Remarks: The mean in one column followed by the same letter wase not significantly different according to DMRT $(\alpha 5 \%)$
\end{tabular}

in the sunken-bed (Table 2).

Harvest index (HI) of rice grown in the sunken-bed was affected by the interaction between the cropping pattern and the fertilizer dose in the raised-bed. In raised-bed with shallot monoculture and intercropping shallot with chili, the reduction of fertilizer dose in raised-beds from the dose of farmer's habits did not affect HI of rice grown in the sunken-bed. The HI differences of rice grown in the sunken-bed occurred when the raised-bed were fertilized with a $50 \%$ or $25 \%$ of the farmer's habits. When the raised-bed was fertilized with $50 \%$ of the farmer's habit, intercropping shallot with chili significantly increased $\mathrm{HI}$ of rice grown in the sunken-bed. When the raised-bed were fertilized with a $25 \%$ dose of the farmer's habit, intercropping shallot with chili decreased $\mathrm{HI}$ of rice grown in the sunken-bed significantly (Table 3 ). It was because reduction of the fertilizer dose in the raised-beds to $50 \%$ farmers' habits was predicted more efficiently, so that crops in the sunken-bed produced and distribute higherplant dry weight higher and increased HI.

Yield component of rice grown in the sunken-bed were not significantly different. This caused the yield of rice grown in the sunken-bed was not significantly different. The results showed that the grain weight per hill and productivity of rice grown in the sunkenbed was not affected by the different cropping pattern and the fertilizer dose in the raised-bed. There was no interaction between both factors in affecting rice yield in the sunken-bed (Table 4).

The results showed that resource utilization by rice grown in the sunken-bed did not differ among treatments. It is suspected that the rice plants in sunken-bed could grow and produce yield, by utilizing the fertilizer runoff from the raised-beds. However, the yield of rice cultivated in Surjan rice field was lower than the description of the varieties used. According to Balai Besar Penelitian Tanaman Padi (2017), Inpari 29 varieties had an average yield of 6.5 tons/ha.

Farmers should implement rice cultivation on the raised-beds with the intercropping shallot with chili, for obtaining higher profits, . The yield of rice under the raised-beds with the intercropping shallot with chili did not decrease significantly. By applying the intercropping shallot with chili in raised-beds and rice grown in the sunken-bed, farmers will get double 
Table 4. Yield per hill and productivity of rice grown in sunken-bed as affected by cropping pattern and fertilizer dose applied in raised-bed

\begin{tabular}{lcc}
\hline Treatment & Yield per hill $(\mathrm{g})$ & Productivity (ton ha $\left.{ }^{-1}\right)$ \\
\hline Cropping pattern in raised-bed (a) & & \\
Monoculture & $8.59 \mathrm{a}$ & $2.15 \mathrm{a}$ \\
Intercropping & $7.97 \mathrm{a}$ & $1.99 \mathrm{a}$ \\
\hline Fertilizer dose in raised-bed (b) & $9.36 \mathrm{p}$ & $2.34 \mathrm{p}$ \\
100\% farmer's habit & $7.59 \mathrm{p}$ & $1.90 \mathrm{p}$ \\
$50 \%$ farmer's habit & $7.90 \mathrm{p}$ & $1.98 \mathrm{p}$ \\
25\% farmer's habit & 8.28 & 2.07 \\
\hline Mean & 7.16 & 26.73 \\
\hline CV a (\%) & 26.58 & \\
CV b (\%) & & \\
\hline Remarks: The mean in one column followed by the same letter wase not significantly different \\
$\quad$ according to DMRT $(\alpha \%)$
\end{tabular}

benefit from shallot, chili, and rice yield.

The yield of rice grown in the sunken-bed did not decrease significantly when the fertilizer dose in the raised-beds was subtracted from the dose of the farmer's habits. To reduce the input, farmers should minimize the fertilizer dose in the raised-beds because it did not cause the decrease of rice yield grown in the sunken-bed. In addition, reducing the fertilizer dose in raised-beds was expected to reduce the negative impact on the environment as a result of the use of inorganic fertilizers. The reduction of fertilizer dose in the raised-beds should be corresponded to the nutrient requirement of shallot as the main crop.

\section{CONCLUSIONS}

The results showed that there was no interaction between the cropping pattern and the fertilizer dose applied in the raised-bed on the growth and yield of rice in the sunken-bed. Compared with shallot monoculture, intercropping shallot with chili in raised-bed decreased the growth of rice in the sunken-bed. Compared with the $100 \%$ fertilizer dose of farmer's habits, the fertilizer dose of $50 \%$ of the farmer's habits in the raised-bed increased the growth of rice in the sunken-bed. However, cropping pattern and fertilizer dose in the raised-bed did not significantly affect the rice yield grown in the sunken-bed of the Surjan rice field.

\section{ACKNOWLEDGEMENT}

The author express her deep gratitude to the DIKTI (Directorate General of Higher Education) for the funding provided to this research.

\section{REFERENCES}

Aminatun, T. 2009. Nilai-Nilai Kearifan Lingkungan Pada Pengelolaan Sawah Surjan Di Kulon Progo. Prosiding Seminar Nasional. Yogyakarta 16 May 2009.

Balai BesarPenelitianPadi. 2012. Deskripsi Varietas Inpari 29. http:// bbpadi. litbang. pertanian. go.id/ index.php/varietas [Accesses 21 December 2016].

Brukin, V., and N. Morozova. 2011. Plant Growth and Development-Basic Knowledge and Current Views. Journal of Math. Model. Nat. Phenom 2(6): 1-55.

Gardner, F. P., R. B. Pearce, and R. L. Mitchell. 2008. Fisiologi Tanaman Budidaya. Penerjemah Herawati Susilo dan Pendamping Subiyanto. Jakarta: Universitas Indonesia Press.

Gover, G., R. Merckx, B. V. Wesemael, and K. V. Oost. 2017. Soil Conservation In The 21st Century: Why We Need Smart Agricultural Intensification. Journal of SOIL (3): 45-59.

Jabbar, A., R. Ahmad, I.H. Bhatti, A. Ur-Rehman, Z.A. Virk, and S.N. Vains. 2010. Effect Of Different Rice-Based Intercropping Systems On Rice Grain Yield And Residual Soil Fertility. Pak J. Bot 42(4): 2339-2348.

Jumakir and Endrizal. 2016. Optimalisasi Lahan Dengan Sistem Surjan Melalui Diversifikasi Tanaman Pada Lahan Rawa Lebak Provinsi Jambi. J.Penelitian Pertanian terapan 1 (17): 26-32

Kurniadie, D. 2001. Pengaruh Kombinasi Dosis Pupuk Majemuk NPK Phonskadan Pupuk N terhadap Pertumbuhan dan Hasil Tanaman Padi sawah Varietas IR 64. J. Bionatura 4(3): 137-147. 
Lindroth, A., F. lagergren, M. Aurela, B. Bjarnadottir, T. Christensen, E. Dellwik, A. Grelle, A. Ibrom, T. Johansson, H. Lankreijer, S. Launiainen, T. Laurila, M. Molder, E, Nikinmaa, K. Pilegaard, B. D. Sigurdsson and T. Vesela. 2008. Leaf area index is the principal scaling parameter for both gross photosynthesis and ecosystem respiration of Northern deciduous and coniferous forests. Jounal of Tellus 60B: 129-142.

Masbidin.2016. Penjelasan Tanaman Tumpang Sari (Polyculture) Lengkap dengan Kelebihannya. http://masbidin.net/tanaman-tumpang sari/ [Accessed 14 February 2017].

Mousavi, S. R and H. Eskandari. 2011. General Overview on Intercropping and Its Advantages in Sustainable Agriculture. J. Appl. Environ. Biol. Sci 1(11 ) 482-486. ISSN: 2090-4215.

Nazemi, D., Y. Rina, I. Ar-Riza, and S. Saragih. 2008. Penerapan Sistem Surjan Untuk Mendukung Diversifikasi dan Peningkatan Pendapatan Di Lahan Pasang Surut Desa Lagan Ulu Kecamatan Geragai Kabupaten Tanjajung Jabung Timur, Jambi". Seminar Nasional: Inovasi untuk Petani dan Peningkatan Daya Saing Produk Pertanian. Balai Penelitian Pertanian Lahan Rawa. Banjar Baru. ISBN 978-979-3450-28-5. Nursyamsi, D.N., and M. Haryono. 2014. Sistem Surjan Model Pertanian Lahan Rawa Adaptif Perubahan Iklim. Jakarta: Badan Penelitian Dan Pengembangan Pertanian. Kementerian Pertanian.
Paudel, M. N. 2016. Multiple Cropping for Raising Productivity and Farm Income of Small Farmers. Journal of Nepal Agricultural Research Council. Vol. 2:3-45.ISSN: 2392-4535 (Print), 2392-4543 (Online).

Pratiwi, G. R. 2005. TanggapPertumbuhan Tanaman GandumT erhadap Naungan. Bogor: Pusat Penelitian dan PengembanganTanaman Pangan. Setiawati, W., R. Murtiningsih, G. A. Sopha, and T. Handayani. 2007. Budidaya Tanaman Sayuran. Balai Penelitian Tanaman Sayuran Hortikultura. BadanPenelitian Dan Pengembangan Pertanian. Shipley, B. 2006. Net Assimilation Rate, Specific Leaf Area And Leaf Mass Ratio: Which Is Most Closely Correlated With Relative Growth Rate? A Meta-Analysis.Jurnal of funct. Ecol. 20: 565-57.

Sianipar, J.E., P. Silitonga, S. Hartono, Sriwidodo, and Dwidjono. 2009. Analisis Fungsi Produksi Intensifikasi Usahatani Padi Di Kabupaten Manokwari. Informatika Pertanian 18(2).

Sitompul, S.M. and B. Guritno. 1995. Analisis Pertumbuhan Tanaman. UGM press, Yogyakarta. Thohiron, M., and H. Prasetyo.2012. Pengelolaan Lahandan Budidaya Tanaman Lahan Terdampak lmpur Marine Sidoarjo.J-PAL 3(1). ISSN: 2087-3522.

Yamuna, B. G., S. B. Yogananda, M. N. Thimmegowda, and B. S. Lalitha. 2017. Effect of maize-based intercropping system on nutrient uptake and yield of crops in southern dry zone of Karnataka. International Journal of Farm Sciences 7(1): 142-146. 